\title{
Martyna Wielewska-Baka*
}

Uniwersytet Gdański

ORCID: 0000-0001-5427-7302

\section{„SZARA PRZESTRZEŃ”. \\ CHARAKTERYSTYKA \\ POSTKOLONIALNEGO I URBANISTYCZNEGO \\ DYSKURSU KRYTYCZNEGO ORENA YIFTACHELA}

\begin{abstract}
Artykuł przedstawia kluczowe narzędzia i metody tzw. krytycznej teorii urbanistycznej zaproponowanej przez Orena Yiftachela, izraelskiego badacza i aktywisty wykładającego na Wydziale Geografii na Uniwersytecie Ben Guriona w Beer Shevie. Autorka omawia fenomen „,szarej przestrzeni” (czy: „miejskich nieformalności”), który doskonale odzwierciedla niższy status niektórych obywateli miejskich, reprezentowany u Yiftachel przez autochtoniczną populację Beduinów. Tego typu zjawisko może być obserwowane również pośród innych zbiorowości w miastach przynależących do globalnego Wschodu czy Południa. Autorka podąża za izraelskim badaczem ku inspiracjom kolonialnym i (neo)marksistowskim, by przedstawić znaczenie pojęć „,pełzającego apartheidu", hegemonii, artykulacji i antagonizmu. Według Yiftachela marginalizowane grupy mają zdolność wyrażania swojej antagonistycznej postawy w miejskich, kulturowych i politycznych praktykach, np. poprzez tzw. sumood czy budowanie pamięci.
\end{abstract}

Słowa kluczowe: Oren Yiftachel, relacje kolonialne, szara przestrzeń, antagonizm, artykulacja, hegemonia

Oren Yiftachel, izraelski badacz zajmujący się m.in. geografią polityczną i urbanistyką, wykładający na Uniwersytecie Ben Guriona w Beer Shevie (BGU- Ben Gurion University of Negev), w swoich publikacjach usilnie nawołuje, by w odniesieniu do izraelskiej polityki przestrzennej i narodotwórczej nawiązywać do paradygmatu kolonialnego, będącego metajęzykiem dla wszelkich innych dyscyplin (Yiftachel 2008: 5). Badacz, proponując mówić o Izraelu jako „etnokracji”, jest autorem publikacji o tytułach niepozostawiających wątpliwości co do inspiracji metodologicznej. Dla zobrazowania warto przywołać książkę pt. Ethnocracy: Land and Identity Politics in Israel/Palestine (2006), napisaną wraz z Alexandrem Kedarem i Ahmadem Amara Emptied Lands: Legal Geography of Bedouin Rights in the Negev, a także współredagowane pozycje: Ethnic Frontiers in Israel: Landscpaes of Development and Inequality in Israel (Yiftachel i Meir 2018), The Power of Planning: Spaces of Control

* Adres do korespondencji: Martyna Wielewska-Baka, Uniwersytet Gdański, Zakład Teorii Literatury i Krytyki Artystycznej, ul. Wita Stwosza 55, 80-308 Gdańsk; e-mail: martyna.wielewska-baka@ug.edu.pl. 
and Transformation (Yiftachel, Little i Hedgcock 2001) czy Hegemonies and Resistance: Israelis in Conflict (Kemp, Yiftachel i Newman Uri 2004). Nomenklatura inspirowana historią kolonialną jest obecna w izraelskiej przestrzeni publicznej, można chociażby przypomnieć bezkompromisową w swojej ocenie książkę Bena White'a pt. Apartheid izraelski. Przewodnik dla poczatkujących, pozycję ,przyswajającą pojęcie apartheidu w celu radykalnej krytyki politycznej działalności Izraela, spadkobiercy imperialnych mocarstw" (Wielewska-Baka 2014: 208). Należy zaznaczyć - co oczywiste - że kolonialne czy postkolonialne nawiązania w praktyce naukowo-badawczej nie przekładają się jednoznacznie na poglądy polityczne. Dla przykładu w wydanej w 2008 roku głośnej książce Kiedy i jak wynaleziono naród żydowski, sprzeciwiającej się nacjonalistyczno-syjonistycznej narracji historii narodu żydowskiego, Shlomo Sand wypowiada wyraźnie, że jego krytyka nie może być traktowana jako głos równoznaczny z głosami przeciwników istnienia państwa Izrael. Zaznaczając tę, miejmy nadzieję niepodważalną różnicę, chciałabym zauważyć, że zagadnienie, kiedy, w jakim celu i w jakich kontekstach pojawia się porównanie historii współczesnego Izraela do historii kolonialnej, jest tematem na osobne, obszerne studia.

Szeroko rozumiane studia nad przestrzenią w ujęciu Yiftachela są, jak możemy wywnioskować z powyższego, nierozerwalnie związane z projektami urbanistycznymi, problemami mniejszości etnicznych czy z kwestiami narodotwórczymi. Nie sposób jednak tutaj przywołać wszystkich pozycji związanych z polityką przestrzenną. Dla polskiego czytelnika ważne pozostaje na pewno nazwisko Artura Jasieńskiego, autora książek pt. Architektura w czasach terroryzmu: miasto, przestrzeń publiczna, budynek oraz Architektura i urbanistyka Izraela - publikacji traktującej o relacji projektów architektonicznych, kwestii narodowego bezpieczeństwa (zagrożenia terrorystycznego) i kształtowania się tożsamości współczesnych Izraelczyków. Warto wspomnieć również pracę pt. Architektura oddzielenia: polityka władz Izraela wobec Palestyńczyków mieszkających na Zachodnim Brzegu Jordanu w pierwszych dekadach XXI wieku Pauliny Codogni.

W niniejszym artykule chciałabym sproblematyzować dwa wybrane z twórczości naukowej Yiftachela zagadnienia: koncepcję „szarej przestrzeni” wraz z przedstawieniem krytycznej teorii urbanistycznej oraz pojęcie hegemonii wraz z opisem strategii oporu. By nie zagubić się w obszernym materiale, chciałabym zawęzić perspektywę do jednej mniejszości etnicznej, której autor poświęca najwięcej chyba uwagi: społeczności beduińskiej z pustyni Negew/al-Naqab w Izraelu. Można tu wtrącić, że dyskurs o narodzinach i rozwoju społeczności beduińskiej jako ludności autochtonicznej jest relatywnie nowym fenomenem na tle trwających od lat 70. XX wieku dyskusji o ludach tubylczych w ogóle (Frantzman et al. 2012: 79). Rok 2005 - przełomowy w świetle braku zainteresowania ideą tubylczości na Bliskim Wschodzie - to formalny początek ruchu, kiedy na dwudziestej trzeciej sesji ONZ poświęconej koncepcji ludów autochtonicznych przedstawiciele Forum Ko-Egzystencji na Negewie zaprezentowali raport o społeczności beduińskiej (Yiftachel był współautorem przemowy). Ismail Abu-Saad, badacz z Wydziału Edukacji na BGU, jako pierwszy umieścił tę mniejszość we współczesnym kontekście politycznym, ustanawiając tym samym początek dyskursu w jego językowym kształcie, m.in. posługując się nie hebrajską nazwą pustyni Negew, ale jej arabskim odpowiednikiem: al-Naqab (Frantzman et al. 2012: 79). Yiftachel 
jest natomiast założycielem naukowego czasopisma „HAGAR. Studies in Culture, Polity and Identities”, którego specjalny numer (2008, 8, 2 został poświęcony wyłącznie arabskiej społeczności Beduinów.

W swoich pracach Yiftachel traktuje autochtoniczność, po pierwsze, jako cechę charakterystyczną ludności beduińskiej, w znaczeniu ,substancjalnej wiedzy o ich historii, walkach i oporze"; po drugie, jako akademicki koncept, w świetle którego daje się porzucić orientalizującą dokumentację „egzotycznych fenomenów” z życia ludów tubylczych, by przejść do polityzującej demaskacji kolonialnych nadużyć i opowiedzieć o stanowczym oporze populacji zyskującej silny głos (Yiftachel 2008: 8). Głos należy oczywiście do marginalizowanej, autochtonicznej ludności Beduinów, ale zamiast powielać kolonialny układ „pana” z metropolii i podporządkowanego z peryferii (Ashcroft et al. 2007: 32-33), izraelski autor dokonuje demontażu struktury binarnych opozycji, tworząc własną siatkę pojęciową. Za najważniejsze można uznać pojęcia „szarej przestrzeni”, hegemonii, artykulacji czy antagonizmu.

\section{„SZARA PRZESTRZEŃ”2 I KRYTYCZNA TEORIA URBANISTYCZNA}

Jedną z bardziej nośnych propozycji formułowanych w ramach języka postkolonialnego mogącej stanowić płodny przedmiot badań dla geografii politycznej, refleksji skupionych wokół idei globalizacji czy studiów miejskich, jest koncepcja tak zwanej „,szarej przestrzeni” (Yiftachel 2008: 9). Gdzie indziej Yiftachel wskazuje również na jej bezpośredni związek z rodzącymi się u progu XXI wieku politykami obywatelstwa miejskiego (Yiftachel 2015: 5). „Szarą przestrzeń” można synonimicznie zastąpić terminem miejskiej nieformalności (urban informality), obejmującej swoim zasięgiem zbiorowość i zabudowania, które nie uzyskały statusu legalnego lub formalnego (Yiftachel 2015: 5). Izraelski badacz wskazuje dwa główne sposoby powstawania tak rozumianych obszarów nieformalnych: odgórny, rzadszy, polegający na „nagięciu albo uniku państwowych regulacji, praw czy planów” przez grupy będące u władzy lub mające silne powiązania, np. przedsiębiorcy korporacyjni czy mafie; oraz oddolny - polegający na szukaniu sposobności polepszenia warunków życia przez społeczności marginalizowane, które dostrzegają nieścisłości/załamania w planach oficjalnych (dotyczących np. imigracji czy planowania miejskiego). Yiftachel wylicza kilka zjawisk obrazujących ten „oddolny” fenomen powstawania „szarych przestrzeni”, np. „niekontrolowany rozwój nieplanowanych zabudowań, »molekularne« rozpraszanie się migrantów zarobkowych czy uchodźców w formalnych częściach miasta, »wkroczenie« wiejskiej, biednej i autochtonicznej mniejszości” i inne (Yiftachel 2015: 6).

Zamieszkująca m.in. czterdzieści sześć nieuznanych przez państwo Izrael wiosek, autochtoniczna ludność arabsko-palestyńskich Beduinów tworzy opisaną przez Yiftachela „szarą

\footnotetext{
Wszystkie tłumaczenia cytatów w tekście głównym oraz te wyodrębnione graficznie pochodzą od autorki.

W artykułach Orena Yiftachela można napotkać wyrażenia synonimiczne: w liczbie mnogiej - gray spaces, z zamienionym określnikiem - gray city, gray cities albo gray urbanism, czy wyrażenie peryfrazujące - urban informality.
} 
przestrzeń", której centrum stanowią okolice Beer Shevy. W północnym regionie pustyni Negew/al-Naqab znaczna część populacji beduińskiej nadal zajmuje ziemie swoich przodków lub - przymusowo wygnana z tych ziem - rezyduje w nowo utworzonych miejscowościach, często również nieuznanych. W wyniku przymusowej relokacji społeczność beduińska, traktowana $\mathrm{w}$ świetle procesu judaizacji jako intruzi bądź najeźdźcy, nie ma dostępu do podstawowych usług, takich jak służba zdrowia, woda i elektryczność, udział w drogach (Yiftachel 2009a: 244). Rezydenci zamieszkujący niesformalizowane obszary mają zatem mocno ograniczony status obywatelski, który ma swoje źródło np. w dyskryminacji ekonomicznej czy tożsamościowej (Yiftachel 2015: 5). Mowa tu nie tylko o powstających dynamicznie wioskach wokół Beer Shevy, ale także o nieuznanej kilkutysięcznej społeczności w samej metropolii - społeczności rezydującej nielegalnie, nieposiadającej reprezentacji we władzach miasta, dostępu do transportu publicznego i edukacji (Yiftachel 2008: 10).

Pojęcia „szarej przestrzeni” czy „miejskiej nieformalności” funkcjonują w literaturze pod nazwą nieformalnych struktur miejskich, miast nieformalnych (informal cities, informal settelments) czy slumsów. Anna Kisiel wiąże nieformalną urbanizację z procesami migracji do miast, brakiem polityki mieszkaniowej, a także wskazuje nań jako na „konsekwencję ubóstwa w sferze potrzeb mieszkaniowych w krajach rozwijających się" (Kisiel 2019: 24). Autorka przytacza również definicję ONZ, „która określa gospodarstwa mieszkalne w slumsach jako grupę poszczególnych osób, zamieszkujących pod tym samym dachem bez dostępu do higieny sanitarnej, bieżącej wody, podstawowej infrastruktury i z ewidentnym brakiem miejsca do życia" (Kisiel 2019: 24). O nieformalnej przestrzeni pisali m.in. Mike Davis, autor Planety slumsów, Karol Kurowski w Samoorganizacji w wielkomiejskim slumsie: przykład Limy czy Justin McGuirk w klasycznej już pozycji pt. Radykalne miasta: przez Ameryke Łacińska w poszukiwaniu nowej architektury. Ten ostatni zauważa, że w ciągu dwudziestu lat w polityce urbanistycznej dokonał się zwrot w kierunku uznania slumsów „za istotny element miejskiego ekosystemu" (McGuirk 2015: 42). Mimo że autor Radykalnych miast jest daleki od traktowania slumsów jako przestrzeni chaotycznych (2015: 42), to sam proces marginalizacji danej zbiorowości i kondycję „,szarych przestrzeni” Yiftachel uważa za zjawiska bardzo niejednoznaczne:

Szarą przestrzeń można zdefiniować jako dynamiczny zbiór ciał, grup, zabudowań i transakcji, które ani nie są formalnie włączone w miejską społeczność i przestrzeń, ani nie są wyłączone czy niszczone. Elementy szarej przestrzeni mieszczą się zatem pomiędzy ,jasnością” pełnej przynależności, rozpoznania, przyzwolenia i bezpieczeństwa a „ciemnością” ekskluzji, odmowy, zniszczenia, wygnania i śmierci (Yiftachel 2015: 6).

Równie trafne i jakże charakterystyczne dla porządku kolonialnego jest inne kontrastowe zestawienie - opisujące ekonomiczno-polityczny status beduińskich enklaw jako oscylujących pomiędzy skrajną „bielą” prawomocności (whiteness of legality/approval/safety) i „czernią” tego, co poddane eksmisji (blackness of eviction/destruction/death; Yiftachel 2008: 9-10). Oparta na metaforyce gradacji kolorystycznej idea „szarej przestrzeni” rozpoznaje m.in. ,puste” obszary prawne, dziury w formalnej polityce miejskiej, która mieści w sobie „obiekty” niepodpadające pod żaden paragraf. Izraelskie ominięcie (nasuwa się wręcz wyraz „obejście”, zgodnie z polskim wyrażeniem „obejść prawo”) kolonialnego, biało-czarnego, drastycznego 
języka dokonuje się tu przez gest rozproszenia, „rozwodnienia”, nadania niejednoznaczności i tymczasowości prawom czy ustawom stosowanym wobec społeczności beduińskiej. Ten wiecznie nieznormalizowany status „bycia pomiędzy” izraelski badacz opisuje nie tylko za pomocą epitetów metaforycznych opartych na gradacji kolorystycznej (,szare przestrzenie”), nie tylko za pomocą kontrastów znanych z kolonialnych nadużyć (biel - czerń, jasność ciemność, bezpieczeństwo - kryminalizacja, legalność - delegalizacja), ale również powołując do życia językowe paradoksy podkreślające chęć zachowania status quo grup dominujących (np. „separująca inkorporacja”, „ciągła tymczasowość”) czy nadając tautologiom logiczne i emocjonalne uzasadnienie (,peryferyjne peryferia” - Yiftachel 2009a: 240).

Czytając prace Yiftachela, nie sposób zatrzeć - niezbyt pozytywnego - wrażenia o niemal kluczowej roli inwencji językowej. W książce o pomysłowym tytule Narzędziownia. Jak badaliśmy (niewidzialne) miasto jej autorzy podejmują temat braku refleksji nad narzędziami stosowanymi w naukach społecznych, zauważając gnębiące owe dyscypliny ,schizofreniczne rozdarcie” polegające na tym, iż ,wiemy, że wszystko jest konstruowane, ale zachowujemy się tak, jakby nic konstruowane nie było" (Drozdowski 2012: 8). Wydaje się, że to brak uniwersalności wypracowanych narzędzi, a także ich zależność od konkretnych uwarunkowań jest przyczyną problemów w warstwie samego wyrażania. W podrozdziale Zalety $i$ wady postugiwania się w nauce pojęciami, które nie pasują do akademickiego żargonu badacze zauważają, iż metafory, metonimie czy alegorie na stałe są już obecne w języku opisu socjologicznego - język bliższy raczej narracji literackiej niż deskrypcji naukowej (Drozdowski 2012: 21).

W odniesieniu do inwencyjnego języka Yiftachela ciekawe wydaje się przywołanie dwóch argumentów na obronę metaforycznego (czy wieloznacznego) języka nauk społecznych. Po pierwsze, autorzy Narzędziowni proponują korzystanie z metodologii tak zwanego średniego zasięgu. Metodologie te miałby charakteryzować m.in. praktycyzm, oparty na „konkretnych rekomendacjach i zalecaniach" sformułowanych w odniesieniu do materiału empirycznego z zastrzeżeniem, iż zakres stosowalności tych rekomendacji nie jest nieograniczony (Drozdowski 2012: 19):

Przynajmniej w jednym przypadku warto jednak podejmować wszelkie rodzaje językowego ryzyka: wówczas, gdy istnieje choćby nikłe prawdopodobieństwo, że ich rezultatem będzie wprowadzenie w szerszy obieg terminu lub terminów, które mają szansę „,przeżyć” projekt. „Przeżyć” choćby w tym najskromniejszym sensie, że inni badacze będą do nich powracać, próbując użyć je do własnych celów (Drozdowski 2012: 49).

Warto zauważyć, że Yiftachelowi nieobce jest poszukiwanie konceptu jak najbardziej użytecznego i dalekosiężnego, który wychodziłby poza ramy społeczeństwa palestyńsko-izraelskiego i odsłaniałby podobne mechanizmy powstawania i funkcjonowania np. reżimów miejskich w innych strefach globalnego Południa i Wschodu. Świetnym przykładem jest komparatystyczne zestawienie dwóch „nieformalnych przestrzeni”, Colombo w Sri Lance i starej Jaffy (dzielnicy Tel Awiwu), miast ulokowanych w „etnokratycznych państwach” (Avni i Yiftachel 2014: 491). Sformułowane przez Yiftachela pojęcia okazują się punktem wyjścia do porównania miejsc odległych i stawiania nowych problemów badawczych, np. tzw. estetyzacji biedy (Avni i Yiftachel 2014: 496). 
Drugim argumentem, na który powołują się badacze z kręgu Narzędziowni w celu obrony wieloznaczności języka nauk społecznych, jest teza nie tylko o interdyscyplinarności wielu współczesnych projektów miejskich, ale również przypomnienie o ich (częstym) zamyśle performatywnym: to ,przedsięwzięcie swoiście interdyscyplinarne, łączące w sobie różne funkcje, poczynając od czysto opisowej, a kończąc na krytyczno-interwencyjnej” (Drozdowski 2012: 24). Co ciekawe, w swojej książce McGuirk pisze o radykalnym podejściu do architektury jako nowym rodzaju praktyki i - po porzuceniu budownictwa socjalnego jako tego, które potrafiło zasypywać podziały społeczne - proponuje wrócić w odniesieniu do slumsów „do idei stosowania metod przestrzennych (niezależnie od tego, czy dotyczą one mieszkalnictwa, transportu czy też placów publicznych), projektowania po to, by łagodzić problemy społeczne" (McGuirk 2015: 46). Performatywny, krytyczno-interwencyjny zamysł autorów Narzędziowni łączy się z pragmatycznym, nieautorytarnym, niedogmatycznym i nieidealistycznym podejściem aktywisty McGuirka:

Urbanistyka w XXI wieku nie dokonuje się w warunkach tabula rasa; każde rozwiązanie zależy od sytuacji zastanej na początku. Pierwsza reguła architekta-aktywisty jest taka, że miasto nieformalne - slums - stanowi fakt, a zaakceptowanie go jako funkcjonującej, produktywnej części miasta, a nie czegoś, co należy zastąpić innym elementem, to jedyna droga naprzód (McGuirk 2015: 48).

Metaforyczny język Yiftachela z pogranicza teorii postkolonialnych i urbanistycznych, dyscyplin społecznych i geograficznych odzwierciedla nie tylko interdyscyplinarność badań, ale również ich zacięcie krytyczne, interwencyjne, aktywizujące. Funkcje te pełnić ma w dużej części postulowana przez Yiftachela nowa krytyczna teoria urbanistyczna (CUT - Critical Urban Theories). Stanowcze (wręcz uporczywe) apelowanie badacza o poszerzenie problematyki w ramach CUT zdaje się mieć źródło co najmniej w czterech przesłankach:

1) obszary miejskiej nieformalności zaczynają być nieusuwalną cechą charakterystyczną współczesnych miast, a według danych Unii Europejskiej z 2009 roku jej objętość szacuje się na ponad dwa miliardy ludzi (Yiftachel 2015: 5);

2) regiony Południa i Wschodu świata obecnie na wielką skalę urbanizują się, lecz w inny sposób niż Północ i Zachód; teorie urbanistyczne liberalnych społeczeństw nie przystają do „szarzejących” stref globalnego Południa i Wschodu (2015: 5-6);

3) samoświadomość grup podporządkowanych stale rośnie i potrafi przybierać różne formy oporu;

4) Yiftachel jest przekonany, że krytyczne teorie do niedawna nie zauważały kolonialnych relacji leżących u podstaw projektowanych i wdrażanych polityk miejskich (Yiftachel 2009a: 247).

Stosując termin „kolonializm”, Yiftachel zastrzega wyraźnie, iż nie chodzi mu o ideowe nawiązanie do kolonializmu europejskiego i wynikających zeń postkolonialnych implikacji. Dyskurs Yiftachela opiera się na głębiej zakorzenionym rozumieniu terminu (tu pojawia się nazwisko np. Agambena), które uwzględnia ogólne - ale często ukryte - relacje władzy: „ekspansję interesów dominujących grup, eksploatację społeczności marginalizowanych, dążenie do ujednolicania tożsamości czy wymuszonej segregacji” (Yiftachel 2009a: 247). Jednocześnie autor mocno zawęża terminologię kolonialną stosownie do własnych zainteresowań, chcąc 
tropić relacje opresji i podporządkowania w projektach miejskich. Stąd biorą się określenia „wewnętrznego kolonializmu” (internal colonialism) czy w różnych konfiguracjach zestawiane pojęcia: colonial, urban, order, relations itp., tworzące w ten sposób matrycę pojęciową krytycznych teorii urbanistycznych.

Nie powinno zatem dziwić, że oparta na segregacji, ekskluzywna, projektująca szereg rozwarstwionych grup o nierównym udziale w miejskich zasobach i prawach, „wybielająca” polityka urbanistyczna zyskuje w teorii Yiftachela miano apartheidu (Yiftachel 2009b: 92). Jednak, jak usiłuje przekonać badacz, współczesne polityki miejskie nie opierają się wyłącznie na jawnych czy zamierzonych procesach dyskryminacyjnych. Nie zaprzecza, że praktyki te są niesprawiedliwe, jednocześnie wskazując na zależność kształtu i charakteru tych praktyk od dogłębnej transformacji we współczesnych miastach:

Gorsza pozycja marginalizowanych szarych przestrzeni i grup nie jest po prostu rezultatem „dyskryminacji”, ale konsekwencją głęboko utrwalonych instytucjonalnych, materialnych i specjalnych systemów, które przyzwalają na nierówny „zestaw” praw i możliwości różnych grup, a także umacniają separację pomiędzy nimi (Yiftachel 2009b: 93).

Chcąc złagodzić brzmienie słowa „niezamierzonej” dyskryminacji, autor proponuje mówić o „pełzającym” apartheidzie, który wkrada się w codzienne zarządzanie procesami urbanizacyjnymi i stopniowo przekształca porządek miejski poprzez wdrażanie różnych regulacji. Często bezwiednie towarzyszą temu codzienne praktyki dyskryminacyjne. Efektem wymienionych działań jest zazwyczaj ograniczenie dostępu do podstawowych usług (np. służby zdrowia, wody czy elektryczności) w obrębie określonej populacji. Okrzepnięcie tak zhierarchizowanej struktury „w relatywnie stały sposób zarządzania metropolią” powoduje powstanie widocznego reżimu miejskiego, czyli „zinstytucjonalizowanego systemu kontrolującego przestrzeń i populację" (Yiftachel 2009b: 93). Znane w geografii politycznej zjawisko reżimu miejskiego czy teorii ustrojów miejskich (Sagan 2000) Yiftachel rozszerza i łączy z naukami socjologicznymi, proponując mówić o zinstytucjonalizowanej logice władzy odzwierciedlanej w przyjętym, „utrwalonym porządku rzeczy” przestrzeni publicznej. Tak pojęty reżim miejski to konfiguracja czynników nie tylko ekonomicznych; to skomplikowany układ procesów zarządzania, polityk tożsamościowych, a także praktyk i norm kulturowych. Dla ustabilizowanych warstw czy grup społecznych umiejętne zarządzanie tym nowym kolonialnym porządkiem jest warunkiem koniecznym, by zachować status quo, dotychczasowe przywileje, a nadto bezpieczeństwo w rzeczywistości głębokich zmian demograficznych (Yiftachel 2009b: 93). W świetle tej ostatniej uwagi nie dziwi fakt, że - jak zobaczymy poniżej - krytyczna teoria urbanistyczna nawiązuje do narzędzi i terminów wypracowanych przez myślicieli marksistowskich oraz ich kontynuatorów.

\section{HEGEMONIA I PRAKTYKI ANTAGONISTYCZNE}

Krytyczna teoria urbanistyczna Orena Yiftachela opiera się w znacznym stopniu na wyraźnie zarysowanej koncepcji hegemonii. Ta teoretyczna podstawa pozwala izraelskiemu badaczowi zauważyć, nazwać i usytuować różne formy oporu w miejskiej przestrzeni, 
a także - co istotne w kontekście poprzedniego rozdziału - lepiej zrozumieć niektóre tezy formułowane w ramach CUT.

Yiftachel traktuje wiele pojęć z zakresu szeroko pojętej teorii postkolonialnej bardzo analitycznie: często bez problematyzowania danego terminu czy bez umieszczania go w kontekstach źródłowych lub reinterpretujących. Dzięki zawężeniu pojęcia hegemonii do interpretacji Antonia Gramsciego oraz Ernesta Laclau i Chantala Mouffe, wywód Yiftachela zyskuje na klarowności, a potraktowana operacyjnie terminologia objawia swój potencjał praktyczny, „,narzędziowy”. Mimo to chciałabym przywołać też innych autorów zabierających głos w debacie na temat hegemonii. Będą to dwaj myśliciele: Raymond Williams (z kręgu marksistowskiego) oraz James Scott (reprezentujący pozamarksistowski punkt widzenia). Dzięki tak poszerzonej perspektywie można nie tylko mocniej „zakorzenić” w tradycji myśl izraelskiego autora, ale również zobaczyć, jak „obfita” w nowe zagadnienia i otwarta na ich podjęcie może być koncepcja Yiftachela.

Yiftachel korzysta z klasycznej już definicji hegemonii. W ujęciu Antonia Gramsciego oznacza ona umiejętne sprawowanie władzy przez klasę dominującą w taki sposób, by „przekonać inną klasę, że ich [klasy dominującej - przyp. M.W.-B.] interesy są interesami wszystkich" przy założeniu, iż dominacja nie polega jedynie na korzystaniu z dosłownie rozumianego aparatu przemocy, ale również na stosowaniu „bardziej subtelnej i inkluzyjnej” siły kształtującej relacje ekonomiczne i kulturowe (Ashcroft et al. 2007: 106). Jeśli zgodzimy się z uwagą Michała Wróblewskiego, iż Gramsci proponuje model społeczeństwa obywatelskiego na wskroś współczesny (Wróblewski 2016: 51), to nie dziwi fakt powoływania się Yiftachela w pierwszych dwóch dekadach XXI wieku właśnie na koncepcje włoskiego marksisty:

W ujęciach inspirowanych myślą Gramsciego tworzenie tożsamości postrzega się jako część nieustającego procesu politycznego. Ujęcia te różnią się od większości marksistowskich czy liberalnych teorii, które traktują kolektywne tożsamości jako prepolityczne. Ciągła zmiana tożsamości w kontekście kontrowersyjnej polityki odnosi się zarówno do klasy burżuazyjnej, wedle Gramsciego formułującej szkielet „biernej rewolucji” rozumianej jako codzienna reprodukcja filarów hegemonicznych; jak i do grup podporządkowanych, które reagują na utrzymującą się opresję [...] walkami i tożsamościami (Yiftachel 2009a: 246).

W Gramsciańskiej myśli hegemonia ma dwoisty charakter, ponieważ zakłada „łączenie przemocy i przyzwolenia" (przemocy aparatu państwowego oraz przyzwolenia na tę przemoc przez nieświadome masy), a także posługuje się narzędziami o dwojakiej naturze: twardej (dyscyplinującej), ucieleśnionej w instrumentarium przede wszystkim polityczno-represyjnym, oraz miękkiej, czyli realizowanej przez wartości etyczno-kulturowe przekazywane w procesie „wychowywania” obywateli (Wróblewski 2016: 117-123). Jednak podczas gdy u Lenina podział na klasy społeczne, mimo formułowania „doraźnej zbieżności interesów” (np. przez klasę robotniczą), nie rozpraszał się na odrębne zbiorowe tożsamości, to Gramsci w swojej definicji praktyki hegemonicznej kładzie nacisk na możliwość transformacji i ,przecinania się” sektorów: „hegemonia rozumiana jako przywództwo moralne i intelektualne wymaga podzielania przez wiele sektorów wspólnych im idei oraz wartości moralnych, kulturowych i intelektualnych” (Morawski 2016: 124). Praktyka hegemoniczna jest zatem ,praktyką tworzenia nowej tożsamości zbiorowej”, która, co więcej, nie ogranicza się do tworzenia 
wspólnej ideologii, ale materializuje się „,w określonych instytucjach, praktykach i rytuałach” (Morawski 2016: 125).

Wyżej zarysowane ujęcie zbiorowej tożsamości jako zjawiska ciągłego i dynamicznego współgra z koncepcją Raymonda Williamsa, który zwraca uwagę na aktywny i procesualny charakter Gramsciańskiej hegemonii. Ta ostatnia nigdy nie istnieje w sposób pasywny: „Hegemonia musi być nieustannie odnawiana, na nowo odtwarzana, broniona i modyfikowana, bowiem jest także nieustannie odrzucana, ograniczana, zmieniana i poddawana próbie za pomocą nacisków z zewnątrz" (Williams 1989: 185). Co więcej, Williams jeszcze silniej akcentuje różnicę między ideologią a hegemonią, z których ta pierwsza oznacza uporządkowany, trwały i abstrakcyjny system znaczeń oraz wartości. Ta druga nigdy nie może zostać sprowadzona jedynie do reprodukowania treści ideologicznych, ponieważ - jak obrazowo przedstawia Williams (1989: 178-180) - ideologia ignoruje życie. Hegemonia, jakbyśmy powiedzieli dziś, wyłania się z bogatej, niejednorodnej sfery bios, ujmując „stosunki panowania i podporządkowania we właściwych formach jako praktyczną świadomość, jako nasycenie nimi całego procesu życiowego - nie tylko politycznej i ekonomicznej działalności, nie tylko określonej społecznej działalności, ale całej materii żywych jednostek i stosunków" (Williams 1989: 180).

Dynamizm, aktywizm i żywiołowość procesu hegemonicznego wydaje się osiągać swój punkt kulminacyjny u Laclau i Mouffe, którzy radykalnie wykraczają poza marksistowsko-gramsciański ekonomiczny fundament klas społecznych i wskazują na absolutnie otwarty i antyesencjalistyczny charakter społeczeństwa. To ostatnie nigdy nie może być traktowane jako zamknięty system. Teza Laclau i Mouffe wydaje się niezwykle trafna, jako że tylko poza całością (społeczeństwem zamkniętym) możliwe jest pomyślenie o swobodnych elementach i praktykach ich wiązania, dzięki czemu rodzą się interesy, rytuały czy instytucje działające w ramach nowych podmiotów społecznych: „Niemożliwość całkowitej i ostatecznej transformacji wszystkich elementów w momenty (innymi słowy: niemożliwość ostatecznej stabilizacji znaczeń, niemożliwość zatrzymania swobodnego dryfowania elementów znaczących) powoduje, że każdą formację dyskursywną będącą rezultatem praktyki wiązania otacza pewna »nadwyżka znaczenia« określona jako pole dyskursywności” (Morawski 2016: 95-96). Parafrazując tę myśl w sposób obrazowy, można stwierdzić, że wyłaniające się w przestrzeni społecznej zbiorowości wydają się posiadać właściwości plastyczne, organiczne wręcz, a wyobrażone jako cząstki podlegają nieustannie zachodzącym procesom chemicznym, reakcjom wiązania, odpychania czy rozpadu.

Owe praktyki wiązania, zwane u neomarksistowskich myślicieli artykulacją, pozwalają Yiftachelowi uwypuklić samą możliwość wyłaniania się zbiorowości przeciwstawiającej się subordynacji czy opresji (Yiftachel 2009a: 247). U izraelskiego myśliciela artykulacja przybiera stricte analityczny charakter, oscylując między skrajnymi pojęciami zaczerpniętymi od Laclau i Mouffe - pomiędzy agonizmem i antagonizmem. Według Mouffe warunkiem funkcjonowania pluralistycznej demokracji jest istnienie agonistycznych napięć, ale w takiej perspektywie, by wróg był postrzegany jako przeciwnik (Morawski 2016: 160). U Yiftachela agonizm definiowany jest jako ,artykulacja różnicy w obrębie dominującego systemu wartości”, natomiast antagonizm - jako ,artykulacja różnicy poza głównym systemem wartości” (Yiftachel 2009a: 246). O ile w agonistycznej opcji możliwe jest funkcjonowanie jakiejś 
społeczności w cieniu zbiorowości hegemonicznej, o tyle antagonizm jest jawnym sprzeciwem wobec hegemonii, jest uświadomieniem o swoich ograniczeniach politycznych, zdaniem sprawy z nieprzekraczalności statusu nierówności. To dlatego Yiftachel pisze o przejściu z agonistycznej opozycji do antagonistycznego radykalizmu, wpisując się w model społeczeństwa otwartego Laclau i Mouffe: „Antagonizm wskazuje na radykalną niemożliwość społeczeństwa jako całości zszytej przez uniwersalną i stabilną narrację, która pojednałaby wszystkie siły polityczne, interesy, cele i grupy społeczne" (Morawski 2016: 102).

Wbrew wyrazistej nazwie antagonistyczna radykalizacja nie przybiera cech heroicznej walki, ponieważ według Yiftachela nie istnieje możliwość „podmiany” obowiązującego, hegemonicznego wzorca. Bezwzględny charakter artykulacji polega na tworzeniu własnej zbiorowej agendy, która w sposób wielokierunkowy, za pomocą różnorakich dyskursów, praktyk, ruchów i przez materialne ukorzenienie będzie formować kolektywną tożsamość.

Yiftachel pokazuje proces stwarzania tej tożsamości, wybierając trzy rodzaje aktywności: sumood, budowanie pamięci i autonomiczną politykę. Arabski termin sumood, będący konsekwencją wydarzeń po 1948 roku, badacz definiuje jako „wytrwałość, cierpliwość i cichą determinację", cechy określające zachowanie Beduinów pozostałych na pustyni Negew/al-Naqab, nieulegających przymusowej urbanizacji i zachowujących dzięki temu swoją tradycję (Yiftachel 2009a: 249). Sumood, rozumiany jako taktyka „nieusuwalnego” sprzeciwu, przejawia się m.in. w nieustannym, uporczywym odbudowywaniu burzonych przez Izraelczyków domów.

Podobnie budowanie pamięci skierowane jest przeciwko zanikaniu, zamazywaniu znaków obecności Arabów od niepamiętnych czasów obecnych w Beer Shevie. Rekonstrukcja tej pamięci odbywa się w trzech porządkach: tradycyjnym, islamistycznym i palestyńskim. Jak same nazwy wskazują, formę tradycyjną przybierają wszystkie działania nakierowane na zachowanie pamięci o Beduinach jako plemiennych „ludziach pustyni”; skupienie na odnowieniu miejsc kultu religijnego, takich jak zapomniane meczety, aktualizują wymiar islamistyczny; z kolei palestynizacja beduińskiej pamięci odbywa się przede wszystkim przez identyfikację Beduinów z używanym przez Palestyńczyków terminem Nakbah, oznaczającym katastrofę roku 1948 (Yiftachel 2009a: 251).

Wreszcie autonomizacja polityki oznacza powołanie do życia takich instytucji, które jawnie będą przeciwdziałały wiekowej praktyce kolonialnej „dziel i rządź”, segregującej społeczność beduińską według kryteriów rasowych, plemiennych czy lokalnych (Yiftachel 2009a: 252).

W myśli izraelskiego badacza artykulacja trzech powyższych form antagonistycznych realizuje nieheroiczny wzorzec sprzeciwu wobec hegemonicznej dominacji. Warto zauważyć, że podobnie „niebohaterskie” ujęcie formy oporu pojawiło się wcześniej u Jamesa C. Scotta. Ewa Majewska, obok Sity bezsilnych (1978) Vaclava Havla, wskazuje właśnie na Weapons of the Weak (1985) Scotta jako na książkę mającą ogromny wpływ na kształtowanie się ,"pojęcia oporu i broni słabych" (Majewska 2019: 10). Scott opowiada nieheroiczną historię chłopów z krajów położonych w południowo-wschodniej Azji: „Ich protesty to na ogół przemarsze, czasem połączone $\mathrm{z}$ artykulacją postulatów, ale czasem polegające po prostu na uporze i niezgodzie na zawłaszczanie ziemi, niegodziwe warunki pracy czy inne nadużycia lokalnych i globalnych możnowładców” (Majewska 2019: 11). Według Scotta „opór jest działaniem, 
które niekoniecznie musi być ukierunkowane na główny obiekt opresji, ale może być także aktywnością ukierunkowaną na zdobycie środków pozwalających na zaspokojenie niezbędnych potrzeb jednostki czy grupy, takich jak: bezpieczeństwo fizyczne, pożywienie, pomieszczenie lokalne, dochód itp.” (Bielska 2013: 262). W świetle krytycznej teorii urbanistycznej oraz wyżej wymienionych form antagonistycznych nietrudno zauważyć, że zwłaszcza w odniesieniu do społeczności beduińskiej można by zastosować pojęcie „słabego”, nieheroicznego oporu, gdzie walka o zaspokojenie podstawowych potrzeb staje się dominującą praktyką antagonistyczną.

W odniesieniu do powyższego można rozważyć również inne ciekawe kwestie związane z prawną interpretacją niektórych zachowań. Różni badacze zarzucali Scottowi tendencję do psychologizowania koncepcji oporu. Jak pisze przytaczający tychże krytyków Wing-Chung Ho, psychologizacja wiąże się ze sprowadzeniem oporu do poziomu empirycznego i próbą odgadnięcia motywów działania indywidualnych osób (co, jak wiadomo, jest trudno mierzalne). Czy na przykład - pyta Ho w imieniu krytyków - bezprawne incydenty będące bezpośrednim rezultatem doświadczanej na co dzień biedy (np. kradzieże, włamania) mogą stanowić przykład form oporu? (Ho 2011: 45). Choć tak postawione pytanie krytyczne wobec koncepcji Scotta wydaje się całkiem zasadne, to w świetle badań Yiftachela traci na znaczeniu. Jeśli izraelski autor tropi m.in. nieheroiczne artykulacje przeciw dominacji, jeśli porusza się w przestrzeni pojmowanej jako nieformalna, to zadanie pytania o tego rodzaju sprzeciw - między bezprawiem a prawem, między ciemnością nielegalnego a jasnością zalegalizowanego - wydaje się pytaniem po prostu chybionym. Pojęcia legalności i nielegalności wywodzą się przecież z porządku hegemonicznego.

\section{ZAKOŃCZENIE}

W niniejszym artykule, odwołując się do przykładu autochtonicznej społeczności beduińskiej, usiłowałam przedstawić kilka głównych pojęć proponowanych przez Orena Yiftachela. Funkcjonują one w dwóch zależnych od siebie porządkach: urbanistycznym i postkolonialnym. Dla krytycznej teorii urbanistycznej postkolonialna siatka pojęciowa stanowi metanarrację, do korzystania z której izraelski badacz nakłania w celu dostrzeżenia mniej lub bardziej jawnych nadużyć czy, po prostu, praktyk dyskryminacyjnych.

Zestawienie koncepcji Yiftachela z innymi pozycjami z zakresu szeroko pojętych studiów nad przestrzenią nakłania do postawienia kilku pytań, z których najbardziej „niecierpliwym” wydaje się pytanie o przydatność „,metodologii średniego zasięgu”. Czy jest ona narzędziem umożliwiającym opis społeczności Palestyńczyków i innych mniejszości etnicznych w Izraelu, na przykład Druzów czy Żydów sefardyjskich? Czy raczej komparatystyczne tło musi pozostać szersze, jak w przypadku porównania Jaffo i Colombo? Czy to ostatnie ujęcie nie powoduje zamazania specyfiki i jednostkowości każdej z tych miejskich nieformalności? Albo, w kontekście inspiracji marksistowskich i pobliskich im teorii, czy jedyną formą oporu w „szarym mieście” jest opór nieheroiczny? Jaki jest związek między niejednoznacznością kondycji przestrzeni nieformalnych a typem rodzącego się tam buntu? Wreszcie, czy koncepcja Yiftachela nie jest formą koncepcyjnego popisu - a nawet jeśli - to czy w tym 
metaforycznym, niejednoznacznym języku nie można po prostu dopatrzyć się desperacko poszukiwanego rozwiązania sytuacji syzyfowego sumood?

Niezależnie od odpowiedzi na powyższe pytania wydaje się, że - przywołując charakter interdyscyplinarny i komparatystyczny badań Yiftachela - zyskujemy prężną i inspirującą wizję krytycznego dyskursu, który, zapewne zależnie od kierunków globalnych ruchów migracyjnych, może stanowić ich teoretyczny „,wewnętrzny kompas”.

\section{BIBLIOGRAFIA}

Amara, Ahmad i Oren Yiftachel. 2014. Confrontation in the Negev. Israeli Land Policies and the Indigenous Bedouin-Arabs, https://www.academia.edu/39233180/CONFRONTATION_IN_THE_NEGEV_Study_commissioned_by_the_Rosa-Luxemburg-Stiftung: 17-26 [27.12.2019].

Ashcroft, Bill, Gareth Griffiths i Helen Tiffin. 2007. Post-colonial Studies. The Key Concepts, London - New York: Routledge.

Avni, Nufar i Oren Yiftachel. 2014. The New Divided City? Planning and „gray space” between global north-west and south-east, w: Susan Parnell i Sophie Oldfield (red.), The Routledge Handbook on Cities of the Global South, London - New York: Routledge, s. 487-505.

Bielska, Ewa. 2013. Koncepcje oporu we wspótczesnych naukach społecznych. Główne problemy, pojęcia, rozstrzygnięcia, Katowice: Wydawnictwo Uniwersytetu Śląskiego.

Codogni, Paulina. 2016. Architektura oddzielenia: polityka władz Izraela wobec Palestyńczyków mieszkających na Zachodnim Brzegu Jordanu w pierwszych dekadach XXI wieku, Warszawa: Instytut Studiów Politycznych Polskiej Akademii Nauk.

Davis, Mike. 2009. Planeta slumsów, tłum. Katarzyna Bielińska, Warszawa: Instytut Wydawniczy Książka i Prasa.

Frantzman, J. Seth, Yahel Havatzelet i Ruth Kark. 2012. Contested Indigeneity: The Developement of an Indigenous Discourse on the Bedouin of the Negev, Israel, „Israel Studies", 17, 1: 78-104.

Jasiński, Artur. 2013. Architektura w czasach terroryzmu: miasto, przestrzeń publiczna, budynek, Warszawa: Wolters Kluwer.

Jasiński, Artur. 2016. Architektura i urbanistyka Izraela, Kraków: Oficyna Wydawnicza AFM.

Kedar, Alexandre, Ahmad Amara i Oren Yiftachel. 2018. Emptied Lands: Legal Geography of Bedoin Rights in the Negev, Redwood City, CA: Stanford University Press.

Kemp, Adriana, Oren Yiftachel, David Newman i Ram Uri (red.). 2004. Hegemonies and Resistance: Israelis in Conflict, Sussex: Academic Press.

Kisiel, Anna. 2019. Nieformalne miasta - wyzwania dla architektury społecznej, „Przestrzeń. Urbanistyka. Architektura", 2: 23-30.

Kurowski, Karol. 2013. Samoorganizacja $w$ wielkomiejskim slumsie: przykład Limy, Warszawa: Wydawnictwa Uniwersytetu Warszawskiego.

Majewska, Ewa. 2019. Słaby opór. Obraz, wspólnota i utopia poza paradygmatem heroicznym, „Praktyka Teoretyczna”, 2, 32: 7-21. 
McGuirk, Justin. 2015. Radykalne miasta: przez Amerykę Lacińska w poszukiwaniu nowej architektury, tłum. Marcin Wawrzyńczak, Warszawa: Fundacja Nowej Kultury Bęc Zmiana: Fundacja Res Publica im. H. Krzeczkowskiego.

Morawski, Karol. 2016. Dyskurs. Hegemonia. Demokracja. Analiza krytyczna projektu demokracji radykalnej E. Laclau i Ch. Mouffe, Warszawa: Wydawnictwo Naukowe PWN.

Rudnicki, Zbigniew B. 2012. Kultura i rozwój jako podstawowe kategorie odniesienia w tworzacym się prawie ludów tubylczych, „Zeszyty Prawnicze”, 12, 4: 7-38.

Sagan, Iwona. 2000. Miasto. Scena konfliktów i wspótpracy, Gdańsk: Wydawnictwo Uniwersytetu Gdańskiego.

Sand, Shlomo. 2011. Kiedy i jak wynaleziono naród żydowski, tłum. Hanna Zbonikowska-Bernatowicz, Warszawa: Wydawnictwo Akademickie Dialog.

Szynkiewicz, Sławoj. 2002. Ofiary wewnętrznej kolonizacji, w: Jarosław Derlicki i Wojciech Lipiński (red.), Pierwsze narody. Społeczności rdzenne i idea tubylczości we współczesnym świecie, Warszawa: Wydawnictwo DiG, s. 17-25.

White, Ben. 2010. Apartheid izraelski. Przewodnik dla początkujacych, tłum. Michał P. Bartolik, Warszawa: Instytut Wydawniczy Książka i Prasa.

Wielewska-Baka, Martyna. 2014. Ahawat Israel. O krytyce i miłości do Izraela. „Jednak Książki. Gdańskie Czasopismo Humanistyczne”, 1: 207-212, https://czasopisma.bg.ug. edu.pl/index.php/JednakKsiazki/article/view/483 [27.12.2019].

Williams, Raymond. 1989. Marksizm i literatura, tłum. Antoni Chojnacki i Edward Kasperski, Warszawa: Państwowe Wydawnictwo Naukowe.

Wing-Hung, Ho. 2011. James Scott's resistance/hegemony paradigm reconsidered, „Acta Politica", 46, 1: 43-59.

Wróblewski, Michał. 2016. Hegemonia i władza. Filozofia polityczna Antonia Gramsciego i jej współczesne kontynuacje, Toruń: Wydawnictwo Naukowe Uniwersytetu Mikołaja Kopernika.

Yiftachel, Oren i Avinoam Meir (red.). 2018. Ethnic Frontiers and Peripheries: Landscapes of Development and Inequality in Israel, New York: Routledge.

Yiftachel, Oren, Jo Little i Alexander Ian Hedgcock (red.). 2001. The Power of Planning: Spaces of Control and Transformation, Dordrecht: Kluwer Academic Publishers.

Yiftachel, Oren. 2006. Ethnocracy: Land and Identity Politics in Israel/Palestine, Philadelphia: University of Pennsylvania Press.

Yiftachel, Oren. 2008. Epilogue: Studying Naqab/ Negev Bedouins - Toward a Colonial Paradigm?, „HAGAR. Studies in Culture, Polity and Identities”, 8, 2: 83-108.

Yiftachel, Oren. 2009a. Critical Theory and Gray Space. Mobilization of the Colonized, „City”, 13, 2-3: 240-256.

Yiftachel, Oren. 2009b. Theoretical Notes on Gray Cities: the Coming of Urban Apartheid?, „Planning Theory”, 8, 1: 87-99.

Yiftachel, Oren. 2015. Epilogue - from Gray Space to Equal Metrozenship? Reflections On Urban Citizenship, „International Journal of Urban and Regional Research”, 39, 4: 726-737. 


\section{"GRAY SPACE".}

THE CHARACTERISTICS OF POSTCOLONIAL AND URBAN CRITICAL DISCOURSE OF OREN YIFTACHEL

This article provides the crucial tools and methods of critical urban theory introduced by Oren Yiftachel, Israeli lecturer and activist in Department of Geography at Ben Gurion University in Beer Sheva. The author analyzes the phenomena of "gray spaces", also termed as "urban informality" which is directly connected to the inferior citizenship's condition of indigenous Bedouins and can be also linked to other populations in global South-East cities. Drawing to the colonial and (neo)Marxist language and relations, the paper invokes the concepts of "creeping apartheid", hegemony, articulation and antagonism. The article argues for rethinking of the subalterns in terms of passive and unconcious groups. Regarding to the thought of Oren Yiftachel, the marginalized populations may articulate their antagonistic strategy by many urban, cultural and political practices, e.g. "sumood" or memory building.

Keywords: antagonism, articulation, hegemony, Oren Yiftachel, colonial relations, gray space

Zgłoszenie artykułu: 29.12.2019

Recenzje: 20.01 .2020

Rewizja: 9.02.2020

Akceptacja: 1.03.2020

Publikacja on-line: 30.03 .2020 